\title{
Domestic Violence against Elderly People: A Case Study of India
}

\author{
Punita Govil, Swati Gupta \\ Aligarh Muslim University (A.M.U.), Aligarh, India \\ Email: punita_govil@rediffmail.com,swt21gupta@gmail.com
}

How to cite this paper: Govil, P. and Gupta, S. (2016) Domestic Violence against Elderly People: A Case Study of India. $A d$ vances in Aging Research, 5, 110-121. http://dx.doi.org/10.4236/aar.2016.55011

Received: June 2, 2016

Accepted: September 2, 2016

Published: September 5, 2016

Copyright $\odot 2016$ by authors and Scientific Research Publishing Inc. This work is licensed under the Creative Commons Attribution International License (CC BY 4.0).

http://creativecommons.org/licenses/by/4.0/ (c) (i) Open Access

\begin{abstract}
The present demographic scenario of the country shows the rising trend of adult population. According to census report 2011, there are $60.3 \%$ people belonging to 15 to 59 years of age group and the percentage of people above $60+$ age is $8.6 \%$. Our country fails to provide due respect, care, affection, security and health related facilities, which elderly people utmost require. A number of cases of adult abuses are reported in news papers as these people are easy victims of violence and criminal activities. The society comes to know about only those problems, which are reported, the innumerable cases of disrespect and neglect are not given any consideration. The situation becomes all the more worst when perpetrators are very near relatives and in some cases blood relatives also. This growing insensitiveness is a threat to our society. Sincere efforts are needed to tackle this alarming problem. The present paper describes the available data [1]-[3] on the old people, their dependence ratio, the problems being faced by them and suggestive measures to provide social and emotional security to them.
\end{abstract}

\section{Keywords}

Domestic Violence, Elderly Abuse, Violent Offenders, Bullying against Elders

\section{Introduction}

The population of the country is passing through the transitional phase. At present more than $50 \%$ of the present population comprises of youth and we may hope that our country would develop fast as the responsibility lies on young shoulders. But the remaining population comprises of $8.6 \%$ old age people or senior citizens whose responsibility is also on young generation. Ageing is a major demographic issue and is faced by all the countries. In 2009, the percentage of old people in the country was $7 \%$ and by 2050 , it would increase up to $20 \%$ of the total population [4]. As a matter of fact, these 
senior citizens who have spent their whole in raising their children or providing them better living, now are subjected to abuse by the hands of their offsprings.

In the present scenario, there is a need to give serious considerations to the wellbeing of elders with special consideration to socio-economic, financial, health, shelter and emotional needs. It's true that nowadays survival is causing stress, especially in joint and extended families, as houses are getting congested. Increase in life span, physical functional disabilities creating need for assistance, generation gap etc. are some of the issues challenging the existence of elder people in the country.

Simply making provisions of food, shelter and health care facilities is not sufficient as they require more than that. Older people in most of the societies are being neglected. They are treated as a burden by the family members. Most of the societies show apathetic attitude towards them. So many cases of elderly abuse come to the light that it is necessary to give a serious thought to the issue so that they may lead their remaining life respectfully with security and care.

The following paragraphs present data related to reported cases of elderly abuse and related issues collected by an NGO "Help Age India" [2]. As in 2015, the data on 'elder abuse in India' is available from the perspective of youths and their experience only and it is not collected from the elderly who have been suffering from abusive incidents, therefore, the present paper discusses the data of Help Age India's Report 2014 on elder abuse. The survey was conducted on a sample of 1200 elderly households of age 60 years and above (100 from each city $\{50 \%$ males and $50 \%$ females $\}$ ) of twelve cities of eight states (Delhi, Kolkata, Mumbai, Bengaluru, Chennai, Hyderabad, Mangalore, Nagpur, Kanpur, Guwahati, Vishakhapatnam and Madurai).

\section{Current Living Arrangement}

At present, $77 \%$ of elderly people live with their family, $14 \%$ with their spouse, $7 \%$ live alone and only $2 \%$ live with their relatives [2]. Table 1 and Figure 1 depict the current living arrangement of elderly people:

In $2013,83 \%$ of elderly people lived with their family, $11 \%$ with their spouse and $6 \%$ lived alone. In 2015, from the perspective of youths $44 \%$ of elderly abused people live with their only son and daughter-in-law, $25.1 \%$ with their son and son's family and daughter, 9.9\% live with their daughter and son-in-law, 8.9\% live in large joint family, $7 \%$ live with spouse or alone, while $2.3 \%$ live with their son or daughter only while any information regarding the residing situation of remaining $2.8 \%$ elderly people has not been assessed [1]-[3].

\section{Prevalence of Abuse}

At the national level, it has been found that $50 \%$ of the elders have experienced abuse personally while $83 \%$ of the elders reported that abusing is prevalent in the society. It is also noticed that $72 \%$ of the abused elderly people belong to the age group 60 - 69 years, $25 \%$ of them belong to the age group $70-79$ and only $3 \%$ of them are of 80 years or above 80 . Females (53\%) reported higher percentage of abusing cases in comparison to 
Table 1. Current living arrangement of elderly.

\begin{tabular}{cc}
\hline Living Status & Percentage \\
\hline With family & $77 \%$ \\
Spouse & $14 \%$ \\
Alone & $7 \%$ \\
Relatives & $2 \%$ \\
\hline
\end{tabular}

Source: Help Age India Report (2014).

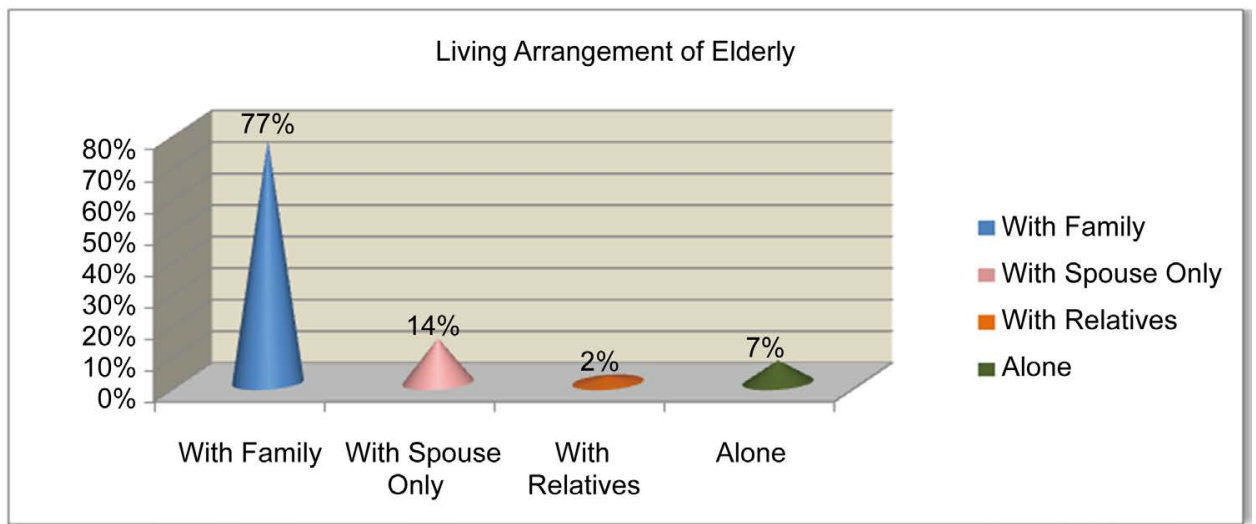

Figure 1. Current living arrangement of elderly.

male elders (48\%). In 2013, the ratio of personal experience of abusing was $23.10 \%$ [1] [2]. It depicts the pathetic condition of elders as the cases of abusing have increased rapidly in one year (Figure 2).

\section{Reasons of Abuse}

The main reasons of elderly abuse are emotional and economic dependence and changing ethos in the society. "Emotional dependence of the abused (46\%)" has emerged as the major reason for the prevalence of elder abuse followed by "economic dependence of the abused (45\%)" and "changing ethos (38\%)" [2]. Table 2 and Figure 3 reveal the reasons of abuse.

In 2013, "lack of adjustment", "economic dependence of the abused" and "increasing longevity" were the main reasons of elderly abuse. In 2015 from the point of view of youth, the main reasons behind elderly abuse are property and inheritance disputes and financial problem in the house (53.2\% and $46.6 \%$ respectively). In the society, "Attitudinal and relationship issues" (35.7\%) have also emerged as the major reason for the prevalence of elder abuse followed by "Lack of time and patience on the part of the abusers (29.4\%)", "Health/addiction problems of abusers (26.9\%)" and "Health/addiction problem of the abused (22.8\%)" [1]-[3].

\section{Reporting of Cases of Elder Abuse}

Among those who experienced abuse, only $59.47 \%$ people made an attempt to report 
Table 2. Distribution of reasons for elderly abuse.

\begin{tabular}{lc}
\hline Reasons & Percentage \\
\hline Emotional Dependence of the Abused & $46 \%$ \\
Economic Dependence of the Abused & $45 \%$ \\
Changing Ethos & $38 \%$ \\
Economic Dependence of the Abuser on the Abused & $30 \%$ \\
Lack of Effective Legal Deterrents & $28 \%$ \\
Increasing Longevity and Need for Care of Older Persons & $9 \%$ \\
\hline
\end{tabular}

Source: Help Age India Report (2014).

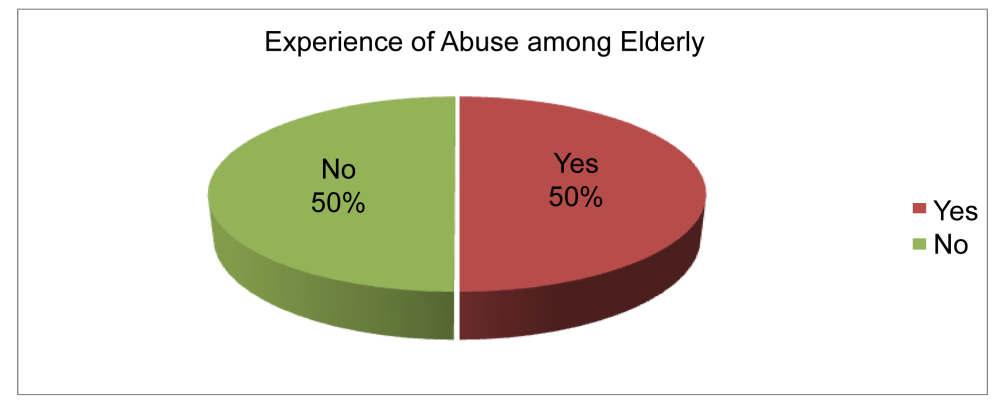

Figure 2. Percentage of abused elderly.

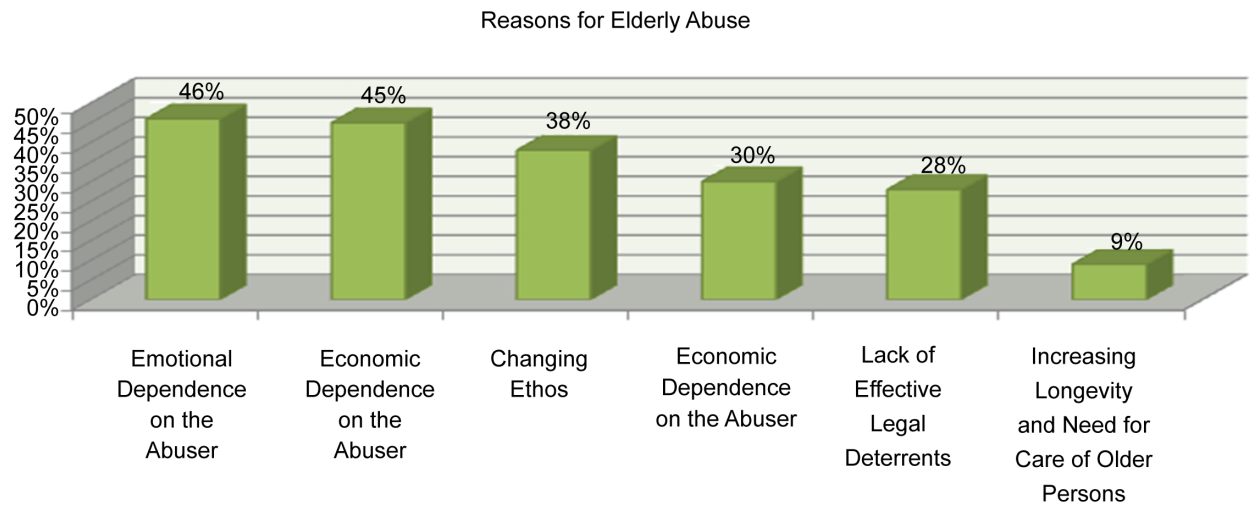

Figure 3. Distribution of reasons for elderly abuse.

the abuse while $40.53 \%$ people didn't report about the abuse that they were facing [2]. Table 3 and Figure 4 show the percentage of elderly who reported or not reported the abuse.

In 2013 , only $30 \%$ elderly people reported the cases of abusing while $70 \%$ people did not report about the abuse that they were facing. This figure explores a high increase in the reporting percentage of elderly abuse from $30 \%$ to $59 \%$ in the year 2014 [1] [2].

\section{Reasons for Not Reporting Abuse}

The elderly who were abused but did not report were asked about the reasons for the 
Table 3. Percentage of reporting of elder abuse.

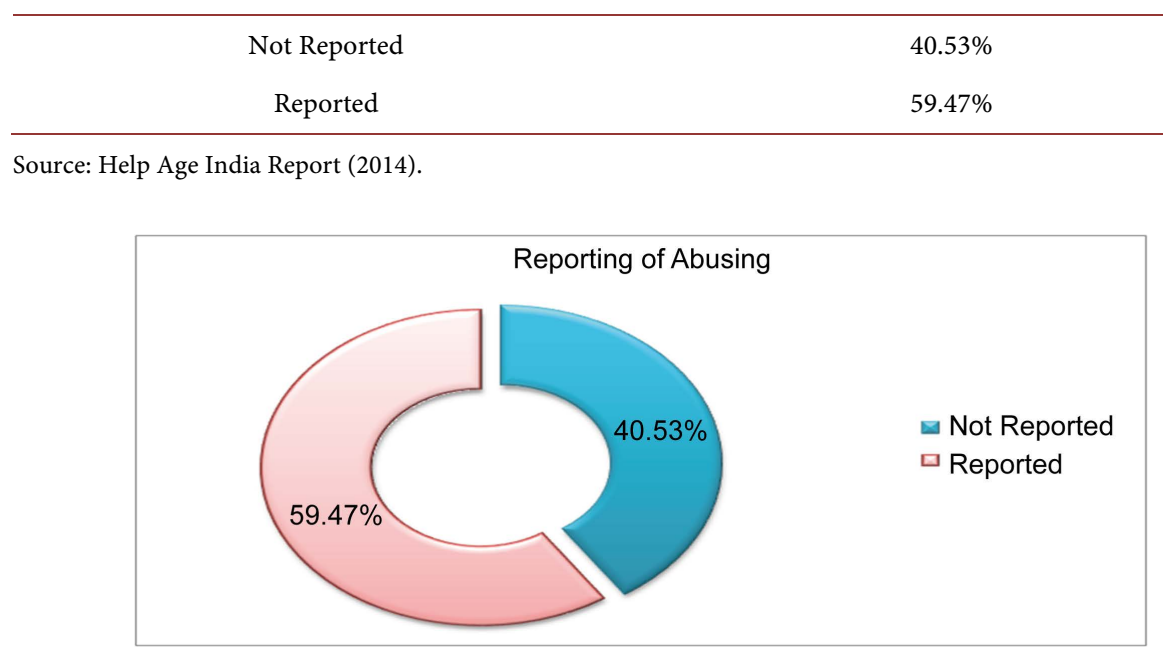

Figure 4. Percentage of reporting of elder abuse.

same. The majority stated that they wanted to maintain confidentiality of family matter (59\%). $17 \%$ of them did not know how to deal with the problems. $13 \%$ of the elders said that they have lack of confidence in any person or agency to deal with the abuse and $11 \%$ did not report for other reasons [2]. Table 4 and Figure 5 present the reasons clearly.

\section{Types of Abuse}

There are various types of abuse, which are faced by elderly people. Verbal abuse (41\%) is the most common type of abuse faced by elderly followed by disrespect (33\%) and neglect (29\%) [2]. Table 5 and Figure 6 reveal this distribution clearly:

In 2013, Disrespect (79\%) was the most common type of abuse faced by elderly followed by verbal abuse (76\%) and neglect (69\%). Economic exploitation (53\%), beating (39\%) and unwelcome sexual contact (3.01\%) were also prevailing abuse in the society. In 2015, according to the youth abusive language or talking rudely (72.4\%) is the most common type of abuse faced by elderly followed by "being isolated/silent treatment/ emotional abuse" (43.1\%) and "denial of basics/medicines/material abuse" (30.1\%). Physical abuse or beating (29.1\%), financial abuse (24.7\%) and unwelcome sexual contact $(1.8 \%)$ are also prevailing abuse in the society [1]-[3] [5].

\section{Perpetrators}

Nationally, daughter-in-law is reported by $61 \%$ as the main perpetrator of abuse and very closely followed by son 59\%. Among these, $7 \%$ elderly abused people reported daughter as the abuser, $6 \%$ reported son-in-law, 3\% reported relative as the abuser and $3 \%$ reported caregiver/servants [2] [6]. Contrary to the present belief, the perpetrators of abuse are shown in Table 6 and Figure 7.

In 2013, daughter-in-law was also reported as the main perpetrator of abuse (39\%) 
Table 4. Reasons for not reporting of abuse.

\begin{tabular}{lc}
\hline Reasons for not Reporting Abuse & Percentage \\
\hline To maintain confidentiality of family matter & $59 \%$ \\
Ignorance of dealing with the problems & $17 \%$ \\
Lack confidence in any person or agency to deal with the abuse & $13 \%$ \\
Other reasons & $11 \%$
\end{tabular}

Source: Help Age India Report (2014).

Table 5. Distribution of different types of abuse.

\begin{tabular}{cc}
\hline Types of Abuse & Percentage \\
\hline Verbal Abusing & $41 \%$ \\
Disrespect & $33 \%$ \\
Neglect & $29 \%$ \\
\hline
\end{tabular}

Source: Help Age India Report (2014).

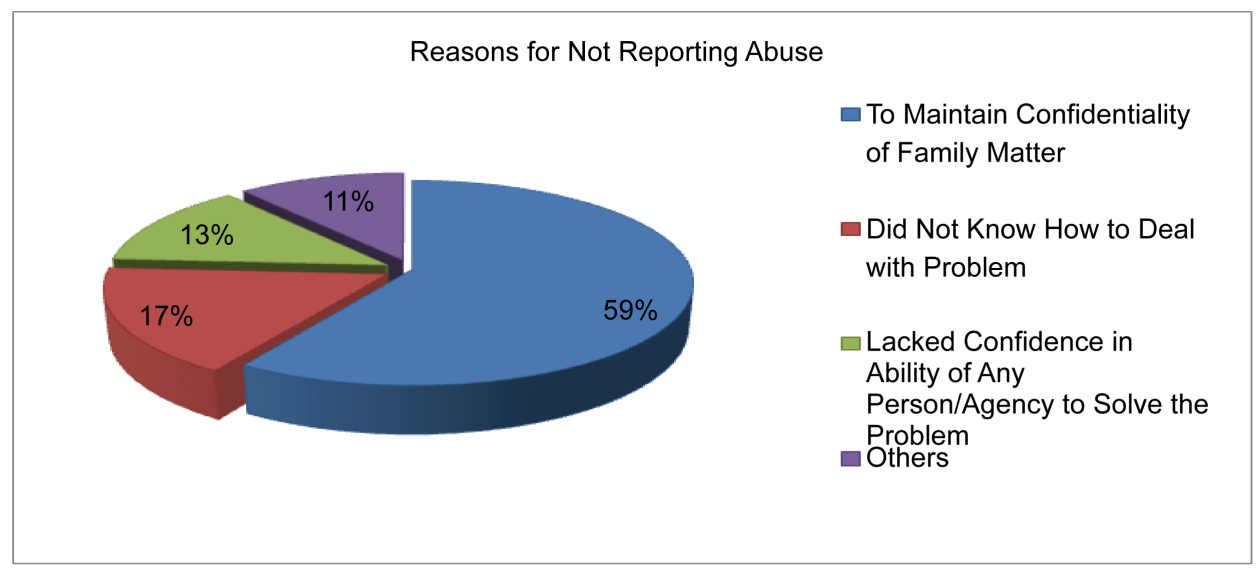

Figure 5. Reasons for not reporting of abuse.

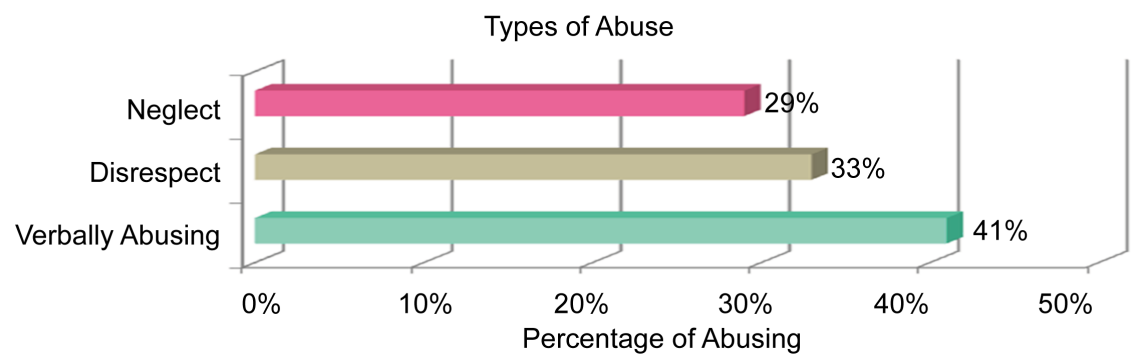

Figure 6. Distribution of different types of abuse.

and very closely followed by son (38\%). However, 6\% elderly abused people reported daughter as the abuser, $4 \%$ stated son-in-law, $5 \%$ reported relative as the abuser, $1 \%$ said caregivers and 5\% reported others as abuser. This figure shows that the main perpetrators of abuse are same over the year. In 2015, the youth of the country reported 
daughter-in-law as the main perpetrator of abuse (50.2\%) followed by son (27.9\%), by other relatives $(24.7 \%)$. Among these, daughters are also found as primary abusers in $20.2 \%$ of the cases followed by grand children (16.1\%), by son-in-law (15.3\%) and by caregivers (6.5\%) [1]-[3].

\section{Duration and Frequency of Abuse}

It was reported at national level that $46 \%$ of elderly have been facing abuse for three to five years, $25 \%$ elderly reported for one to two years, $21 \%$ stated that the duration is approximate six to ten years. About $4 \%$ of the abused elders have been facing the same situation for more than fifteen years and equal percentage of elderly (4\%) have been facing the abuse for eleven to fifteen years. The abused elders also stated that $35 \%$ of them are abused at least once in a weak, $20 \%$ elderly face it once in a month, $17 \%$ said that they encounter with abusing almost daily, while $15 \%$ reported that they come across to abuse very rarely and only $13 \%$ of them face the abuse once in few months [2]. Table 7 and Figure 8 depict the picture clearly.

\section{Awareness of Redress Mechanism}

In the society, there are various mechanisms to report the cases of elder abuse as Police Help Line, Maintenance Act 2007 and Tribunal under MWPSC etc. It is found that 64\% elderly are aware about Police Help Line and it is the most commonly known redress mechanism for elder abuse. 14\% are aware of Maintenance and Welfare of parents and

Table 6. Perpetrators of abuse.

\begin{tabular}{cc}
\hline Daughter-in-law & $61 \%$ \\
Son & $59 \%$ \\
Daughter & $7 \%$ \\
Son-in-law & $6 \%$ \\
Relative & $3 \%$ \\
Caregiver/Servant & $3 \%$ \\
Other & $6 \%$ \\
\hline
\end{tabular}

Source: Help Age India Report (2014).

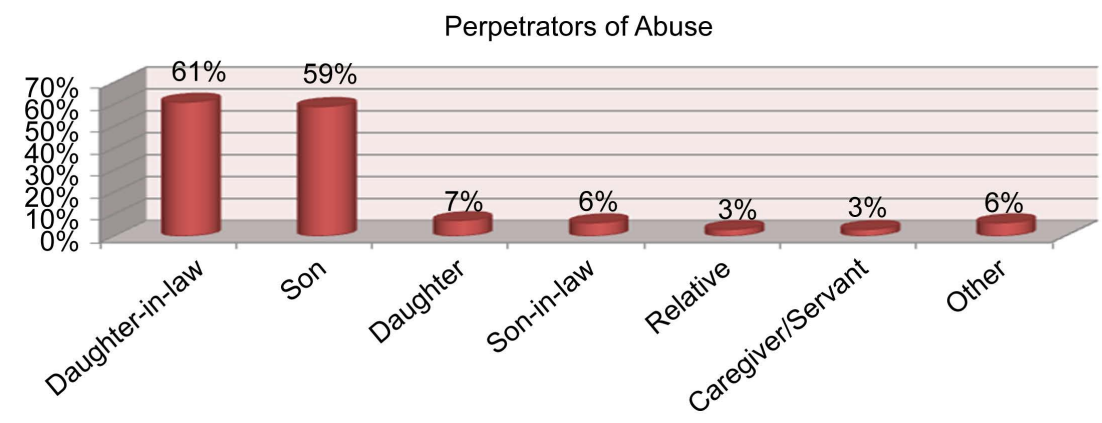

Figure 7. Perpetrators of abuse. 
Table 7. Duration and frequency of abuse.

\begin{tabular}{cccc}
\hline Duration of Facing Abuse & Percentage & Frequency of Abuse & Percentage \\
\hline$>15$ Years & $4 \%$ & Once in a Weak & $35 \%$ \\
$11-15$ Years & $4 \%$ & Once in a Month & $20 \%$ \\
$6-10$ Years & $21 \%$ & Almost Daily & $17 \%$ \\
$3-5$ Years & $46 \%$ & Very Rarely & $15 \%$ \\
$1-2$ Years & $25 \%$ & Once in a Few Months & $13 \%$ \\
\hline
\end{tabular}

Source: Help Age India Report (2014).

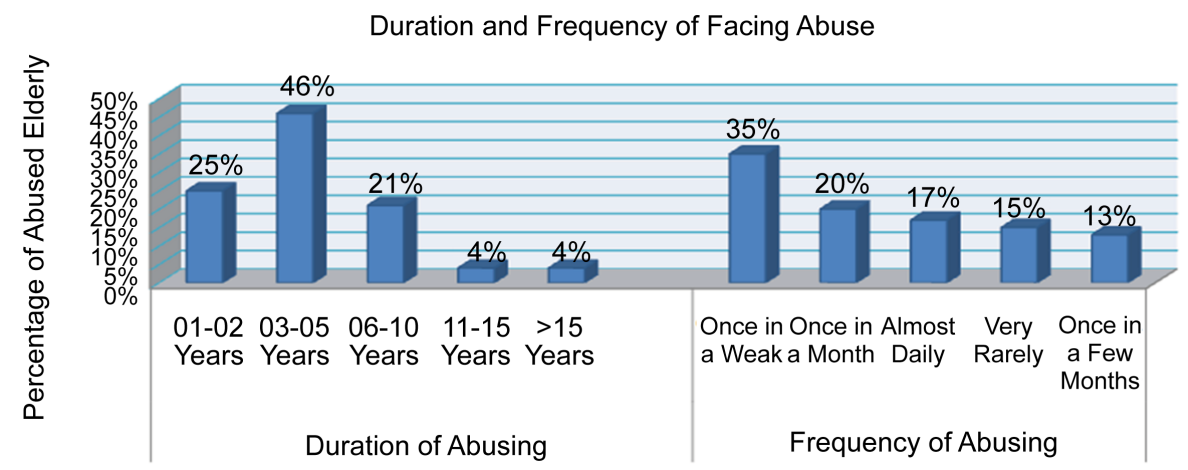

Figure 8. Duration and frequency of abuse.

Senior Citizens Act 2007 while 10\% are aware of Tribunal under MWPSC Act, 9\% elder people reported that they are aware of Help Age India's Elder Helpline number and $18 \%$ elder people are not aware of any redress mechanism [2]. Table 8 and Figure 9 clearly depict this percentage.

In 2013, Police Help Line was also the most commonly known redress mechanism for elder abuse (69.64\%) followed by NGO and Help Age India's Elder Helpline number (17.67\%) and Maintenance and Welfare of parents and Senior Citizens Act 2007 $(10.92 \%)[1][2]$.

\section{Legal Provisions for the Adults in the Country}

There was the time when Indian society was proud of its joint family system. Elders were respected and had a voice in family matters. With the passage of time, situation changed completely. Disintegration of joint family system and emergence of nuclear or single family norms are the effects of industrialization. Migration, consumerism and various allied features have given birth to value erosion. Similarly, due to increase in medical facilities life expectancy which was as low as 32 years in 1947 has gone up to 69 in 2011. As a result of these factors, incidents of elderly abuses, neglect and abandonment are frequent. Many of them suffer even physical abuses. Even cases of murder are also frequent.

According to National Crime Records Bureau in 2014 [7], 18714 incidences of crime have been reported against senior citizens and as a whole the rate is $18.3 \%$. Table 9 
Table 8. Awareness of various redress mechanisms among elderly.

\begin{tabular}{lc}
\hline Mechanisms & Percentage \\
\hline Maintenance Act 2007 & $14 \%$ \\
Tribunal Under MWPSC Act & $10 \%$ \\
Police Help Line & $64 \%$ \\
Help Age India's Help Line & $9 \%$ \\
Other & $5 \%$ \\
None & $18 \%$ \\
\hline
\end{tabular}

Source: Help Age India Report (2014).

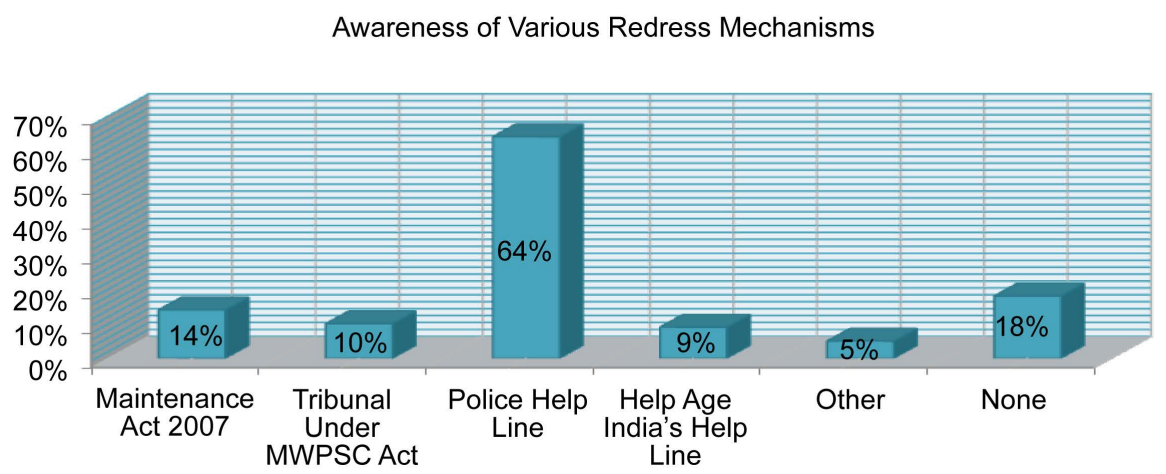

Figure 9. Awareness of various redress mechanisms among elderly.

Table 9. Description of various crimes against senior citizens.

\begin{tabular}{cccc}
\hline No. & Nature of Crime & Number & Percentage (\%) \\
\hline 1 & Cheating & 1567 & $8.4 \%$ \\
2 & Robbery & 1184 & $6.3 \%$ \\
3 & Murder & 1115 & $6 \%$ \\
4 & Grievous Hurt & 1069 & $5.7 \%$ \\
\hline
\end{tabular}

describes the nature of crime and corresponding number and percentage:

Among the states where maximum number of crime were reported is Maharashtra (21.3\%, 3981 cases) (literacy rate: 82.91$)$, followed by Madhya Pradesh (18.4\%, 3438 cases) (literacy rate: 70.63$)$, Tamil Nadu (11.3\%, 2,121 cases) (literacy rate: 80.33 ), and Andhra Pradesh (9.9\%, 1,852 cases) (literacy rate: 67.66). As a whole on every one lakh elderly population 18 people are victims of crime under IPC. Delhi has reported maximum rate of crime (89\%) (literacy rate: 86.33 ), followed by Madhya Pradesh (60.2\%) (literacy rate: 70.63), Andaman and Nicobar Island (47.2\%) (literacy rate: 86.27), Goa (44.6\%) (literacy rate: 87.40), Chhattisgarh (41.6) (literacy rate: 71.04), Andhra Pradesh (38.3) (literacy rate: 67.66) and Maharashtra (35.8) (literacy rate: 82.91).

Out of these horrible data, a total case of 1115 are of murder and in this area Tamil Nadu reported 171 cases followed by Uttar Pradesh (170 cases), Maharashtra (167 
cases) and Madhya Pradesh (116 cases) etc.

Although, the constitution provides various legal provisions for the safe guard of senior citizens, constitution also provides them legal provisions to live their life in respectful manner, yet the situation is very pathetic. The following paragraphs provide a glimpse of various legal provisions for elderly people:

1) Hindu Adoptions \& Maintenance Act, 1956 [8] for the first time made provisions for maintenance for aged parents according to the discretion of the court. In deciding the amount of maintenance, the position and status of claimant, reasonable desires, current living situation (separately/with family) and the value and income from the property of claimant should be taken into consideration. But at that time there was hardly any reported case of harassment or elderly abuse.

2) Another Act came in 1973. Section 125 of criminal procedure code (1973) [9] also provides maintenance from children but in India, cases are rarely reported. This Act ensures maintenance up to 500/ per month only for those elderly parents who are unable to maintain themselves. Non-compliance of the order may lead to legal punishment according to the provisions.

3) The most recent is the MWPSC Act 2007 (Maintenance and Welfare of Parents and Senior Citizens) [10]-[12] which secures fundamental rights of senior citizens who has attained the age of 60 years or more. For the first time, the act provides the meaning of each and every word and subsequent explanation. According to the Act, senior citizens are those Indians who have attained the age of 60 and the term "parents" means mother and father, "children" means adult son, daughter, grandson, granddaughter and any other beneficiary. According to this Act, parents and grandparents who are unable to maintain themselves from their own income can demand maintenance up to 10,000. The Act states government to open and manage old age homes, each to accommodate 150 elderly people. Section 24 of the Act mentions punishment of Rs. 5000/with imprisonment of 3 months to those who abandon their parents or elderly people.

\section{Discussion}

From the above discussion it is clear that there is significant increase in the number of crimes against old people. This situation is sufficient to make us feel shame. Although the percentage of crime by unknown persons and professionals is quite high but alarming situation for us are the substantial incidences of crime against elderly people by family members, relatives, caregivers, nears and dears and even neighbours. In most of the cases reported so far perpetrators of crime are daughter-in-law, son and daughter.

Another issue is related with apathetic attitude of society and non-reporting of such incidences. Only those cases, which go beyond the manageable limits are reported otherwise members of society and even sufferers just bear the pain as they feel going the matter outside the home is disgraceful. This non-reporting of cases also encourages perpetrators. Members of society just regard these incidences as family matter and do not take any action.

The data reveals that emotional and economic dependence on the abusers is the main 
cause of abusing. Erosion of values, apathetic attitude of society, financial crises and health related issues of elders are some of the causes leading to the abuse. Absence of meaningful social attachment among older people and other family members to some extent is also responsible. Attitude and relational issues also add fuel to the fire. In most of the cases, elderly people were victimized of being alone as they have no choice to stay alone.

Another issue is related to lack of awareness about redress mechanism of legal provisions for the incidences of elderly abuse. All these causes together make the situation worse.

Simply presenting the data and fixing the responsibilities is not sufficient to deal with the problem. Active participation of community members is essential. Youths are to be sensitized. Even elderly people themselves must be made aware of legal provisions and to take cautionary measures. Senior citizen cells may be established in every district. Elderly helpline should effectively work. Police should also pay attention about the security of those who are living alone. Inter-personal relationship among family members should be strengthened. Speedy, effective, efficient redress mechanism is needed to ensure the safe and happy life to elderly people.

The main point of discussion is why we are so unconcerned about those who have nurtured us. This growing empathy and negligence may be due to insensitive attitude, growing economic considerations and dependency. Government is trying its best at various levels like old age pensions are given to make them economic independent. Various NGOs also work and provide a helping hand to them. But it is the responsibility of each one of us to take some steps so that abusing may be reduced. It is true that government alone cannot solve the problem. The contribution of each one of us is necessary. Education has to sensitize youths and strengthen inter generation bonding. Youths are to be made sympathetic and responsible citizens. If such cases are found in the society, immediate social reporting and legal steps should be taken to redress the problem. It is very painful to see that those hands which nurtured us, made us develop what we are today, are begging for little affection, little care and due respect. We hope that this paper would serve as a catalyst for awakening the society and remind each one of us to give our parents everything of their share.

\section{References}

[1] Help Age India (2013) Elder Abuse in India. New Delhi. http://www.helpageindiaprogramme.org/index.aspx

[2] Help Age India (2014) Elder Abuse in India. New Delhi.

[3] Help Age India (2015) A Youth Perspective on Elder Abuse (Elder Abuse: The Indian Youth Speaks Out). New Delhi.

[4] Census of India (2011) Provisional Census. censusindia.gov.in

[5] The Times of India (June 17, 2015) Delhi Most Uncaring towards Elderly among Metros: Survey. Aligarh, p. No. 8.

[6] The Times of India (June 15, 2014). Son and Daughter-In-Law Torment Elderly. Aligarh, p. No. 8. 
[7] National Crime Records Bureau (2014) Crime in India. Ministry of Home Affairs, Government of India, East Block-7, R.K. Puram, New Delhi. http://ncrb.gov.in

[8] Hindu Adoption and Maintenance Act (1956). http://tcw.nic.in/Acts/Hindu\%20adoption\%20and\%20Maintenance\%20Act.pdf

[9] Maintenance for Women, Children \& Parents Under Section 125 (1973) CR.P.C. https://sites.google.com/site/lawofwomen/maintenance-under-different-act/maintenance-u nder-section-125-cr-p-c

[10] Maintenance and Welfare of Parents and Senior Citizens Act 2007 (2007) Ministry of Law and Justice, New Delhi.

[11] Mishra, A.J. and Patel, A.B. (2013) Crimes against the Elderly in India: A Content Analysis on Factors causing Fear of Crime. International Journal of Criminal Justice Sciences, 8, 1323.

[12] The Times of India (June 15, 2014) Provision for Parents to Claim Monthly Maintenance. Aligarh, p. No. 8.

Submit or recommend next manuscript to SCIRP and we will provide best service for you:

Accepting pre-submission inquiries through Email, Facebook, LinkedIn, Twitter, etc. A wide selection of journals (inclusive of 9 subjects, more than 200 journals)

Providing 24-hour high-quality service

User-friendly online submission system

Fair and swift peer-review system

Efficient typesetting and proofreading procedure

Display of the result of downloads and visits, as well as the number of cited articles Maximum dissemination of your research work

Submit your manuscript at: http://papersubmission.scirp.org/ 